\title{
Characterization of the Potential Mercury Contamination in the Apolobamba Gold Mining Area, Bolivia
}

\author{
Caracterización de la contaminación potencial por mercurio en el área minera de \\ Apolobamba, Bolivia \\ Caracterização da potencial contaminação por mercúrio na área mineira de \\ Apolobamba, Bolivia
}

\section{AUTHORS}

Received:25.03.2011 | Revised: 11.07.2011 | Accepted: 12.07.2011

Acosta J.A. ${ }^{10}$

ja.acosta@upct.es

\section{Martínez-}

Martínez S.

Faz A. ${ }^{1}$

Millán R. ${ }^{2}$

Muñoz M.A. ${ }^{1}$

Terán T.

Vera R. ${ }^{2}$

( Corresponding

Author

${ }^{1}$ Departamento de

Ciencia y Tecnología

Agraria. Universidad

Politécnica de

Cartagena. Paseo

Alfonso XIII, 52.

Cartagena. 30230.

Murcia. Spain

${ }^{2}$ Centro de

Investigaciones

Energéticas,

Medioambientales

y Tecnológicas.

Madrid. Spain.

\section{ABSTRACT}

A large amount of $\mathrm{Hg}$ is used for gold extraction through the amalgamation process in the Apolobamba gold mining area located in the northwest part of La Paz, Bolivia. This mining operation may produce a very serious impact on the ecosystems, as well as on the health of miners and inhabitants, mainly due to the primitive methods used in the gold recovery. The objective of this work was to characterize the potential contamination of total $\mathrm{Hg}$ in soils, sediments, water, and plants in a mining area of Bolivia. Results showed that there was atmospheric deposition of $\mathrm{Hg}$ in the study area. Accumulation of this metal in the studied soils and sediments was one of the highest in the world, but $\mathrm{Hg}$ in aquatic solution was below the detection limit of the analytical method of the studied lakes and rivers. The highest concentration of $\mathrm{Hg}$ was found in the river sediments of the SunchullíViscachani (102 mg kg-1), and in the sediments of Sunchullí and Viscachani lakes (12.3 and $11.7 \mathrm{mg}$ $\mathrm{kg}^{-1}$, respectively). These concentrations may pose a serious problem for aquatic life, related ecosystems and human health. Therefore, there is a need to study $\mathrm{Hg}$ availability and speciation in soils and sediments to better understand the cycling of $\mathrm{Hg}$ in the area.

\section{RESUMEN}

Una gran cantidad de Hg se utiliza para la extracción de oro mediante el proceso de amalgamación en la zona minera de Apolobamba, localizada al noroeste de La Paz, Bolivia. Este tipo de actividad puede estar generando un impacto muy grave tanto para los ecosistemas, como para la salud de los mineros y habitantes de la zona, principalmente debido a los métodos poco tecnificados utilizados en la recuperación del oro. El objetivo de este estudio fue caracterizar la contaminación potencial que supone la presencia de Hg total en suelos, sedimentos, agua y plantas. Los resultados mostraron que existía una deposición atmosférica activa de $\mathrm{Hg}$. La acumulación de este metal en los suelos y sedimentos estudiados fue una de las más altas a nivel mundial; sin embargo, el $\mathrm{Hg}$ en la solución acuosa estuvo debajo del limite de detección del método analitico utilizado en los lagos y ríos estudiados. La mayor concentración de Hg se encontró en los sedimentos del Rio Sunchulli-Viscachani (102 $\mathrm{mg} \mathrm{kg}^{-1}$ ) y en los sedimentos de los lagos Sunchulli y Viscachani (12,3 y 11,7 $\mathrm{mg} \mathrm{kg}^{-1}$, respectivamente). Estas concentraciones pueden suponer un grave problema para los animales acuáticos, los ecosistemas asociados y la salud humana. Por lo tanto, existe una urgente necesidad de estudiar la biodisponibilidad y la especiación del $\mathrm{Hg}$ en suelos y sedimentos para comprender mejor el ciclo del Hg en esta área. 


\section{RESUMO}

Na zona mineira de Apolobamba, localizada a Noroeste de La Paz, utilizam-se grandes quantidades de Hg no processo amalgamação para extracção de ouro. Este tipo de actividade pode ser responsável por graves impactos quer para os ecossistemas quer sobretudo para a saúde dos mineiros principalmente devido às tecnologias pouco avançadas que são utilizadas na recuperação do ouro. O objectivo deste estudo foi a potencial contaminação que pressupóe a presença de $\mathrm{Hg}$ total nos solos, sedimentos, água e plantas. Os resultados obtidos mostraram a existência de uma deposição atmosférica activa de $\mathrm{Hg}$. A acumulação deste metal nos solos e sedimentos estudados foi uma das mais elevadas a nível mundial; contudo, os teores de Hg na solução aquosa encontrrvam-se abaixo do limite de deteç̧ão do método analítico utilizado, para os lagos e rios estudados. A maior concentração de $\mathrm{Hg}$ foi detectada nos sedimentos do rio Sunchulli-Viscachani (102 $\left.\mathrm{mg} \mathrm{kg}^{-1}\right)$ e nos sedimentos dos lagos Sunchulli e Viscachani (12,3 y 11,7 $m g \mathrm{~kg}^{-1}$, respectivamente). Estas concentrações sugerem graves problemas para as espécies aquáticas, ecossistemas associados e saúde humana. Existe assim, uma necessidade urgente de estudar a biodisponibilidade e especiação do Hg nos solos e sedimentos, para melhor compreender o ciclo do Hg nesta zona.

\section{KEYWORDS}

Pollution, soil, environmental impact, sediments, water, heavy metals

PALABRAS

CLAVE

Polución, suelo, impacto ambiental, sedimentos, agua, metales pesados

PALAVRAS-

CHAVE

Poluição, solo, impacto ambiental, sedimentos, água, metais pesados 


\section{Introduction}

The "Apolobamba Integrated Management National Area (ANMINA)", located in the northwest part of the Department of La Paz, Bolivia, is a very important gold mining region. Currently, gold is extracted using a $\mathrm{Hg}$ amalgamation technique that represents a highly economical and practical technique since 1556 (Enríquez 2001). Hg amalgamation is based on the formation of a gold-Hg alloy which is subsequently heated to volatile $\mathrm{Hg}$ to obtain pure gold. Unfortunately, this method leads to massive $\mathrm{Hg}$ contamination in the mining area (Ramirez and Terán, 2002).

More than 40000 tons of $\mathrm{Hg}$ were disseminated in the environment during the colonial time in Bolivia (Enríquez 2001). At least 25-50 tones of $\mathrm{Hg}$ per year are discharged in the environment in Bolivia (Ministerio de Minería Metalurgia de Bolivia 1993). In addition, the use of firewood of diverse plant species as fuel for heating ovens caused a successive deforestation and degradation of the region (Ramirez and Terán, 2002).

The studied area has around 100 mining cooperatives and they are all located in alluvial plains in the Andean Bolivian Plateau. Mining operations use very primitive equipment and are carried out mostly by women and children. Miners work at night and even in abandoned mines in order to be able to survive (Enríquez 2001). The houses are located next to the mines and along the river. The inhabitants of these areas consume fish from the lakes and rivers, and they use the waters for the livestock, domestic purposes, and irrigation.

Studies were first initiated during the 1980s to determine the environmental impact of the mining activities. In 1993, the National Secretary of the Environment (SENMA) carried out an evaluation of the mining and industrial sectors in Bolivia and concluded that the main impacts on the environment derived from the mine activity were: consumption of exhaustible and scarce resources (land use, removal of minerals, and water use); transformation of the landscape; pollution of surface water, groundwater and soils; and accumulation of solid wastes and emissions of dust containing heavy metals that can contaminate water and soils (Enríquez 2001). Recent exploratory studies also found significant $\mathrm{Hg}$ contamination in sediments, river waters and other water bodies (Maurice-Bourgoin et al. 2001), and fish (Alanoca and Maurice-Bourgoin 2000).

Although previous research efforts pointed out the importance of determining the most suitable preventive measures in the area (Alanoca and Maurice-Bourgoin 2000; Maurice-Bourgoin et al. 2001), local and national authorities have had great difficulties controlling the mining operations. This is due to the isolated occurrence of many small cooperative mines, the absence of serious efforts by qualified staff, and the lack of infrastructures. All of these factors collectively contributed to the development of the present critical environmental conditions.

$\mathrm{Hg}$ is among the most highly toxic trace metals in the food chain and many national and international agencies and organizations are interested in developing methods for its possible emission control (Horvat et al. 2003). Hylander et al. (1994), studying the Hg content of the Pantanal ecosystem in Brazil, indicated that $\mathrm{Hg}$ originated in the amalgamation process showed higher bioavailability than $\mathrm{Hg}$ naturally present in soil minerals. These authors found that catfish (Pseudo-platystoma coruscans) had a Hg content above the limit for human consumption (0.5 ppm w.w.) and significantly above the natural background level.

$\mathrm{Hg}$ transfer and transport in watersheds are well understood (USEPA, 2000). The elemental Hg $\left(\mathrm{Hg}^{\circ}\right)$ can travel from its source to the final receptor following a multi-step sequence, which includes emission to the atmosphere, transportation and deposition. Travnikov (2005) studied the dispersion of $\mathrm{Hg}$ in the atmosphere of the Northern hemisphere, and suggested that the contribution of external anthropogenic and natural sources to $\mathrm{Hg}$ deposition to different continents varies from $30 \%$ to $70 \%$ of the total value. This author concluded that the contribution of the intercontinental atmospheric transport of $\mathrm{Hg}$ is comparable with that of regional pollution even in industrially developed regions of the Northern hemisphere.

In general, $\mathrm{Hg}$ is believed to be relatively inert with a strong volatility under most atmospheric conditions (Zang-Ho et al. 2005). Thus, $\mathrm{Hg}^{\circ}$ is not 


\section{Material and Methods}

easily oxidized to less volatile forms by the major oxidants $\left(\mathrm{O}_{3}, \mathrm{OH}\right.$, etc.); so its residence time is estimated in the range of 1-2 years (Lindquist and Rhode 1985).

Recent estimates of global anthropogenic emission of $\mathrm{Hg}$ are in the range of $2000-2600 \mathrm{Mg} \mathrm{yr}^{-1}$ (Pirrone et al. 1996; Pacyna and Pacyna, 2002; Pacyna et al. 2006). The global oceanic emission is estimated to be $800-2600 \mathrm{Mg} \mathrm{yr}^{-1}$ (Bergan et al. 1999; Mason and Sheu, 2002; Lamborg et al. 2002) and the global natural terrestrial emission is estimated to be $1000-3200 \mathrm{Mg} \mathrm{yr}^{-1}$ (Lindberg et al. 1994; Bergan et al. 1999; Shia et al. 1999; Mason and Sheu, 2002; Lamborg et al. 2002; Seigneur et al. 2004). These estimates give a global natural $\mathrm{Hg}$ emission of $1800-5800 \mathrm{Mg} \mathrm{yr}^{-1}$.

The objective of this work was to determine the total $\mathrm{Hg}$ in soils, sediments, plants, and waters in three selected areas affected by gold mining in comparison to regulatory threshold levels.
Study area and sites descriptions

The study area is located in the protected area of "Apolobamba", $68^{\circ} 30^{\prime}-69^{\circ} 20^{\prime}$ west and $14^{\circ}$ $40^{\prime}-15^{\circ} 10^{\prime}$ south, La Paz Province, Bolivia. Three different gold mining districts affected by $\mathrm{Hg}$ pollution (Campo, 2003) were selected for our study: Sunchullí-Viscachani, Katantica, and Sural (Figure 1).

In order to determine the extension of $\mathrm{Hg}$ pollution in the study area, soil, sediment, water and plant samples were collected. In addition, for comparing surface $\mathrm{Hg}$ with subsurface $\mathrm{Hg}$ concentration, and therefore evaluating atmospheric deposition, soil profiles were selected and sampled. Each soil, sediment, water, and plant sample was collected in triplicate and mixed in the field.

Soil samples were taken using a soil spade, with the caution of avoiding contamination between samples, cleaning the spade before use for each sample. Soil samples were taken between 0 to $15 \mathrm{~cm}$ depth. Sediment samples were

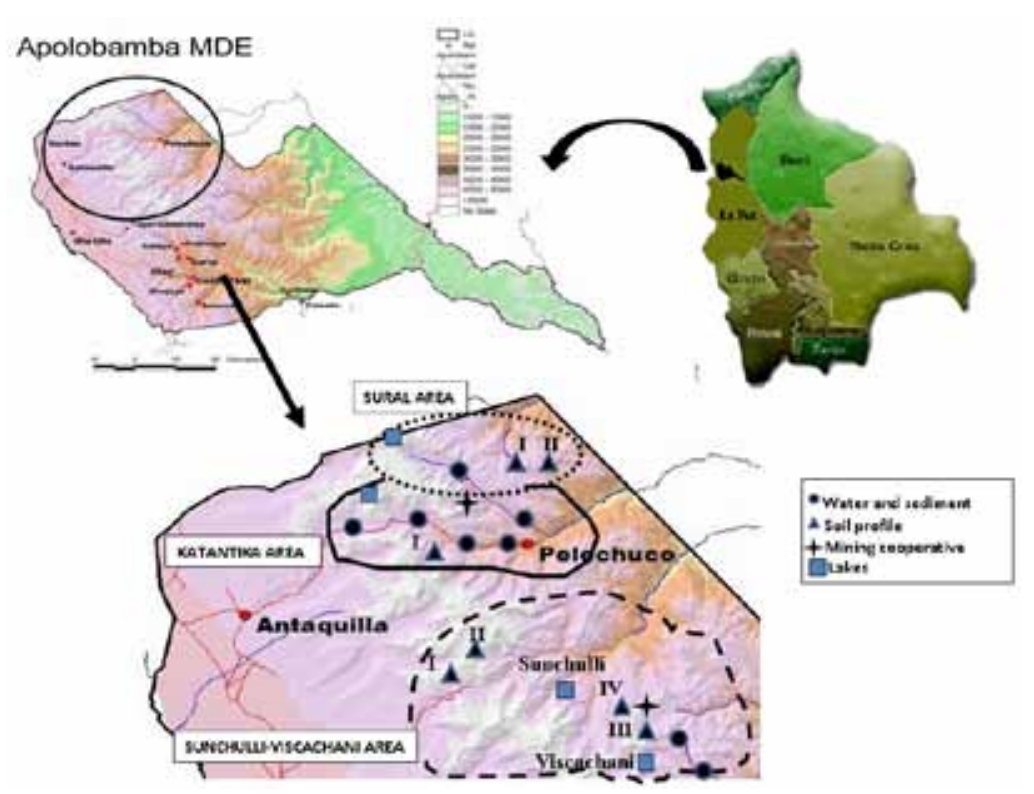

Figure 1. Sampling map and location of the three studied areas. Surface soil samples were collected around the lakes and mining cooperatives (not shown in the map). 
taken using a long spade, in order to take the samples separated from the river or lake shore and as closer as possible to the center of the river bed, and as far as possible from the lake's shore. Plant samples from the same species were taken and stored in polyethylene bags with some holes to avoid water condensation and putrefaction. They was pressed and dried for its identification.

Soil and sediment samples were stored in polyethylene bags, while water samples were stored in hydrochloric acid washed high-density polyethylene bottles. All samples were stored at 4 ${ }^{\circ} \mathrm{C}$ and water samples were kept in light dark conditions using opaque bottles prior to sample preparation and analysis.

\section{- The Sunchullí-Viscachani area}

Four soil profiles were sampled in the Sunchullí-Viscachani area. Soil profiles were classified according to the World Reference Base (WRB 2006): a Fibric Histosol (Profile I), an Haplic Cambisol (Profile II), and two Haplic Regosols (Eutric) (Profile III and IV) (Table 1). Profile I (formed by three horizons: $\mathrm{H} 1$ $(0-12 \mathrm{~cm}), \mathrm{H} 2(12-23 \mathrm{~cm})$, and $\mathrm{R}(>23 \mathrm{~cm}))$ and Profile II (formed by four horizons: $\mathrm{H}(0-9$ $\mathrm{cm})$, Ah $(9-24 \mathrm{~cm})$, Bw $(24-40 \mathrm{~cm})$, and C/R $(>40 \mathrm{~cm}))$ were located $6 \mathrm{~km}$ northwest from Sunchulli Lake and $18 \mathrm{~km}$ from the main mining operation site, in the north face side of the mountain range (Figure 1). These profiles were sampled to find out whether there was a long distance atmospheric deposition of $\mathrm{Hg}$ in the area. Profile III (formed by four horizons: Ah $(0-11 \mathrm{~cm}), A C(11-22 \mathrm{~cm})$, and $C$ $(>22 \mathrm{~cm})$ ) and Profile IV (formed by four horizons: Ah (0-12 cm), C1 (12-32 cm), 2C2 (32$54 \mathrm{~cm})$, and $2 \mathrm{C} 3(>54 \mathrm{~cm})$ ) were located less than $500 \mathrm{~m}$ from the main mining operation site.

Three surface soil samples were taken around Sunchullí Lake (0-15 cm depth), located $5 \mathrm{~km}$ northwest from the main mining operation site. In order to evaluate the accumulation of $\mathrm{Hg}$ on the water bodies bed, seven sediment samples were taken: three in
Sunchullí Lake, two in Viscachani Lake, and four in the Sunchullí River (two upstream and two downstream a discharge point). Seven water samples were collected in the same location where the sediments were taken: three from the Sucnhullí Lake, two from Viscachani Lake, and two from the Sunchullí River. The most abundant plant species (Aciachne sp.) growing in the main mining operation area was sampled, including roots and aerial part. This species is the most common plant growing in the Pycnophyllum grasslands from Bolivia (Seibert, 1993; Muñoz and Faz, 2009), which is dominant in the Apolobamba highlands. Two mine residual samples from a pyramidal pile of $5 \times 6 \mathrm{~m}$ base and $2 \mathrm{~m}$ high close to the mining operation area were collected; also three soil samples were sampled from this site for analysis.

\section{- The Katantika area}

The Katantica area is located in the north part of the Apolobamba gold mine area, close to the Sural, and includes three different rivers: the Pelechuco River, the biggest one, the Turcos River, and the Rayo Rojo River. The mining activity in this area, like in the other areas, is principally associated with gold extraction but in this case the extraction is carried out from two different materials: auriferous grey quartz and alluvial deposits coming from upstream and located at the bottom of the rivers.

In the Katantika area, a soil profile (Profile I), formed by two horizons: Ah $(0-42 \mathrm{~cm})$ and $\mathrm{C}$ $(>42 \mathrm{~cm})$ and located $1 \mathrm{~km}$ from the mining operation, was studied and classified as an Haplic Umbrisol (WRB, 2006). Two sediment samples in the Katantika Lake and four in the Pelechuco River (two samples upstream and two downstream a discharge point) were collected. Six water samples were taken at the same point than the previous sediments and finally, one mine solid residue from three pyramidal piles of $3 \times 4 \mathrm{~m}$ base and $1 \mathrm{~m}$ high close to the mining operation area was collected. In addition, a sediment sample and a water sample were also collected in a small 
stream draining from the main Katantika mining operation area.

\section{- The Sural area}

The smallest gold mining area included in this study, the Sural area, is located in the northwest part of Apolobamba. In this region the principal gold extraction is from alluvial deposits in the lower part of the river, and the gold distribution is controlled by the sediment structure affected by surface runoff. Profile I, formed by two horizons: Ah $(0-9 \mathrm{~cm})$ and R (> $9 \mathrm{~cm}$ ), and Profile II, formed by the horizons $\mathrm{H}(0-27 \mathrm{~cm})$ and $\mathrm{R}(>27 \mathrm{~cm})$, were taken 5 $\mathrm{km}$ southeast from the Sural Lake and $1 \mathrm{~km}$ east from the Sural River, and were classified as a Lithic Leptosol and a Fibric Histosol, respectively (WRB, 2006). Two superficial soils located $1 \mathrm{~km}$ from the mining operation area, two sediments, and two water samples were collected in the Sural Lake. One water sample in the Sural River was also taken. Finally, one plant sample (Aciachne sp.), including roots and aerial part, was collected in the shore of the Sural River.

Analytical treatment

Soil samples were dried at $30^{\circ} \mathrm{C}$ for $24 \mathrm{~h}$, passed through a $2 \mathrm{~mm}$ steel sieve, and grounded with a mechanical agate mortar (Retsch RM 100) for $10-$ $15 \mathrm{~min}$ before analyses. Sediment samples were dried and grounded but not sieved because they were composed of particles less that $2 \mathrm{~mm}$. Plants were washed with deionized water, oven-dried at $70^{\circ} \mathrm{C}$ for 48 hours and grounded for $\mathrm{Hg}$ analysis.

Soils and sediments were characterized for: pH (Peech 1965), organic carbon (Anne 1945; Duchafour 1970), total nitrogen (Duchafour 1970), electrical conductivity (Bower and Wilcox 1965), particle size distribution using Robinson Pipette method (FAO-ISRIC, 2006), and cation exchange capacity (Chapman 1965).

The water samples were filtered and stored in the refrigerator at $4{ }^{\circ} \mathrm{C}$. An Advanced $\mathrm{Hg}$ Analyser (AMA-254, LECO company) was used, with a detection limit of $0.5 \mathrm{ppb}$ on weight basis. This equipment use solid samples, thus it is not necessary any digestion of the samples. Reagent blanks and reference materials were used as the quality control samples during the analysis. Certified reference materials (CRM) were used to determine the accuracy and precision of the measurements and to validate the applied method. They were obtained from the Community Bureau of Reference (BCR). These certified reference materials consist of SRM 2709 (soil, $1.40 \pm 0.08 \mathrm{mg} \mathrm{kg}^{-1}$ of Hg), CRM 62 (Olea europea, $0.28 \pm 0.02 \mathrm{mg} \mathrm{kg}^{-1}$ of $\mathrm{Hg}$ ), and BCR 281 (Rye grass, $0.020+0.002 \mathrm{mg} \mathrm{g}^{-1}$ ).

Bolivia and Spain do not have any legislation allowing the classification of a polluted soil according to its $\mathrm{Hg}$ concentration. Therefore, reference values from Holland $\left(0.3 \mathrm{mg} \mathrm{kg}^{-1}\right)$, Belgium $\left(0.55 \mathrm{mg} \mathrm{kg}^{-1}\right)$, France $\left(1 \mathrm{mg} \mathrm{kg}^{-1}\right)$, Germany (2 $\left.\mathrm{mg} \mathrm{kg}^{-1}\right)$, United kingdom (1 $\left.\mathrm{mg} \mathrm{kg}^{-1}\right)$ and Switzerland $\left(0.8 \mathrm{mg} \mathrm{kg}^{-1}\right)$ have been used to evaluate the degree of $\mathrm{Hg}$ enrichment of the sediment and soil samples (NMHPPE 1994; BWRHABTGG 1995; Barth and L'Hermite 1987; BAFUB 1987). It should be kept in mind that these guidelines pertain to soil samples and not sediments. 


\section{Results and Discussion}

The Sunchullí-Viscachani area

The $\mathrm{Hg}$ contents of the topsoil from the four profiles in this area were $0.38,2.58,9.94$, and 2.96 $\mathrm{mg} \mathrm{kg}^{-1}$. In comparison, the concentrations in the subsoil were $0.09,0.34,1.27$ and $0.23 \mathrm{mg}$ $\mathrm{kg}^{-1}$ (Table 1). These results suggest that atmospheric deposition of $\mathrm{Hg}$ could have taken place in this area for all the studied profiles. However, some studies have shown that in many tropical areas $\mathrm{Hg}$ is frequently high in soils, possibly as a result of the atmospheric deposition of $\mathrm{Hg}$ over thousands to perhaps millions of years (Lechler et al. 2000). Thus, it is possible that the observed values from Profile I represent the natural accumulation of $\mathrm{Hg}$ in the topsoil.

Table 1. Properties and $\mathrm{Hg}$ contents of soil profiles, surface soils, plant, mine wastes, water and sediments in the Sunchullí-Viscachani area

$$
\begin{array}{ccccccc} 
& \text { E. C. } & \text { O.C. } & \text { C.E.C. } & \text { T. N. } & \text { Clay } & \mathrm{Hg} \\
\mathrm{pH} & \left(\mathrm{dS} \mathrm{m}^{-1}\right) & \left(\mathrm{g} \mathrm{kg}^{-1}\right) & \left(\mathrm{cmol}_{+} \mathrm{kg}^{-1}\right) & \left(\mathrm{g} \mathrm{kg}^{-1}\right) & \left(\mathrm{g} \mathrm{kg}^{-1}\right) & \left(\mathrm{mg} \mathrm{kg}^{-1}\right)
\end{array}
$$

Profiles

\begin{tabular}{|c|c|c|c|c|c|c|c|}
\hline Profile I - H1 (0-12 cm) & 5.55 & 0.20 & 96.6 & 30.57 & 7.7 & 176.8 & 0.38 \\
\hline Profile I - H2 (12-23 cm) & 5.77 & 0.21 & 45.4 & 11.90 & 3.4 & 112.0 & 0.09 \\
\hline $\mathrm{R}(>23 \mathrm{~cm})$ & -- & -- & -- & -- & -- & -- & -- \\
\hline \multicolumn{8}{|l|}{ Haplic Cambisol } \\
\hline Profile II - H $(0-9 \mathrm{~cm})$ & 6.91 & 0.25 & 6.2 & 5.26 & 0.8 & 69.3 & 2.58 \\
\hline Profile II - Ah (9-24 cm) & 5.41 & 0.06 & 27.6 & 9.80 & 2.6 & 146.5 & 0.05 \\
\hline Profile II - Bw $(24-40 \mathrm{~cm})$ & 6.61 & 0.05 & 16.8 & 7.43 & 1.5 & 81.5 & 0.08 \\
\hline Profile II - C/R (> $40 \mathrm{~cm})$ & 5.44 & 0.19 & 19.2 & 5.76 & 1.4 & 89.7 & 0.34 \\
\hline \multicolumn{8}{|l|}{ Haplic Regosol (Eutric) } \\
\hline Profile III - Ah $(0-11 \mathrm{~cm})$ & 5.13 & 0.16 & 39.2 & 12.36 & 3.4 & 156.0 & 9.94 \\
\hline Profile III - AC (11-22 cm) & 5.27 & 0.12 & 27.0 & 11.01 & 2.1 & 127.3 & 0.05 \\
\hline Profile III - C (> $22 \mathrm{~cm})$ & 5.88 & 0.06 & 5.8 & 3.63 & 0.5 & 79.6 & 1.27 \\
\hline \multicolumn{8}{|l|}{ Haplic Regosol (Eutric) } \\
\hline Profile IV - Ah $(0-12 \mathrm{~cm})$ & 5.09 & 0.73 & 71.0 & 14.41 & 5.9 & 208.5 & 2.96 \\
\hline Profile IV - C1 (12-32 cm) & 4.55 & 0.51 & 40.1 & 15.78 & 3.6 & 259.5 & 1.97 \\
\hline Profile IV - 2C2 (32-54cm) & 5.31 & 0.17 & 20.8 & 12.28 & 1.6 & 161.9 & 0.22 \\
\hline Profile IV - 2C3 (> $54 \mathrm{~cm})$ & 5.12 & 0.32 & 16.3 & 11.64 & 1.5 & 125.1 & 0.23 \\
\hline \multicolumn{8}{|l|}{ Soils } \\
\hline Soil 1 & 5.54 & 0.18 & 102.0 & 29.95 & 8.7 & 169.2 & 203 \\
\hline Soil 2 & 5.85 & 1.29 & 8.0 & 1.15 & 0.7 & 30.7 & 12.8 \\
\hline Soil 3 & 4.52 & 0.27 & 50.8 & 23.66 & 6.3 & 127.4 & 5.13 \\
\hline \multicolumn{8}{|l|}{ Plant } \\
\hline Plant & -- & -- & -- & -- & -- & -- & 1.84 \\
\hline \multicolumn{8}{|l|}{ Mine waste } \\
\hline M1 & 6.35 & 3.26 & 34.2 & 1.50 & 0.3 & 35.6 & NM \\
\hline M2 & 2.18 & 5.72 & 02.3 & 0.59 & 0.4 & 21.8 & 3.45 \\
\hline
\end{tabular}

Fibric Histosol 


\begin{tabular}{|c|c|c|c|c|c|c|c|}
\hline \multicolumn{8}{|l|}{ Sunchullí River } \\
\hline $\begin{array}{l}\text { Sediment (1) upstream } \\
\text { discharge }\end{array}$ & 6.34 & 0.230 & 11.6 & 4.18 & 1.2 & 40.8 & 4.14 \\
\hline $\begin{array}{l}\text { Sediment (2) downstream } \\
\text { discharge }\end{array}$ & 4.85 & 1.180 & 16.6 & 2.99 & 0.9 & 52.8 & 102 \\
\hline $\begin{array}{l}\text { Water (1) upstream } \\
\text { discharge }\end{array}$ & 6.96 & 0.150 & -- & -- & -- & -- & BDL \\
\hline $\begin{array}{l}\text { Water (2) downstream dis- } \\
\text { charge }\end{array}$ & 6.91 & 0.148 & -- & -- & -- & -- & $\mathrm{BDL}$ \\
\hline \multicolumn{8}{|l|}{ Sunchullí Lake } \\
\hline Soil (4) & 7.88 & 1.22 & 7.6 & 2.96 & 1.2 & 61.5 & 0.78 \\
\hline Soil (5) & 6.63 & 0.06 & 6.6 & 6.68 & 1.5 & 177.6 & 1.2 \\
\hline Soil (6) & 7.51 & 0.82 & 7.9 & 3.59 & 1.8 & 101.0 & 0.06 \\
\hline Sediment (3) & 7.19 & 0.41 & 10.6 & 1.18 & 0.5 & 12.9 & 12.3 \\
\hline Sediment (4) & 6.31 & 0.11 & 18.3 & 7.17 & 2.7 & 339.4 & 0.1 \\
\hline Sediment (5) & 7.02 & 0.21 & 11.9 & 3.29 & 1.2 & 76.8 & 4.14 \\
\hline Water (3) & 6.96 & 0.203 & -- & -- & -- & -- & $\mathrm{BDL}$ \\
\hline Water (4) & 6.90 & 0.187 & -- & -- & -- & -- & BDL \\
\hline Water (5) & 7.06 & 0.192 & -- & -- & -- & -- & $\mathrm{BDL}$ \\
\hline \multicolumn{8}{|l|}{ Viscachani Lake } \\
\hline Sediment (6) & 5.74 & 0.56 & 218.3 & 34.74 & 16.7 & 205.1 & 11.7 \\
\hline Sediment (7) & 5.77 & 0.04 & 89.5 & 42.56 & 9.0 & 277.2 & 23.7 \\
\hline Water (6) & 6.57 & 0.048 & -- & -- & -- & -- & $\mathrm{BDL}$ \\
\hline Water (7) & 6.65 & 0.045 & -- & -- & -- & -- & $\mathrm{BDL}$ \\
\hline
\end{tabular}

BDL: below the detection limit $\left(0.5 \mu \mathrm{g} \mathrm{L}^{-1}\right)$; NM: not measured due to saturation of equipment; E.C.: electrical conductivity; O.C.: organic carbon; T.N.: total nitrogen; C.E.C.: cation exchange capacity.

Oppositely, Profiles II, III, and IV showed a much higher concentration in the topsoil than in the subsoil, indicating active atmospheric deposition of $\mathrm{Hg}$; therefore, for these profiles the $\mathrm{Hg}$ was originated from the atmospheric deposition and not from the bedrock. The Hg can be transported in small particles in the air and cause problems in the breathing system (Peñaloza and Reinhardt, 2000). These particles could reach the agricultural soils and pastures near the mine areas by atmospheric transport.

According with the used regulations, all the surface horizons have a $\mathrm{Hg}$ concentration higher than the reference values (NMHPPE, 1994; BWRHABTGG, 1995; Barth and L'Hermite 1987; BAFUB 1987), except for Profile I. Therefore, all the profiles in the area studied can be considered as anthropogenic Hg-enriched with the exception of the Fibric Histosol (Profile I).

As shown in Table 1, the effect of atmospheric $\mathrm{Hg}$ deposition in the Sunchullí-Viscachani area was visible in the soil surface layers (Soils 1, 2 and 3) with a highest concentration up to $203 \mathrm{mg} \mathrm{kg}^{-1}$. This and other analytical data confirm that this area likely make one of the most heavily polluted area with $\mathrm{Hg}$ in the world, which poses a very high risk for human population and terrestrial ecosystems. In fact, some authors have reported maximum levels of $\mathrm{Hg}$ of $3.4,1.9,54,4.2,40$, and $2.4 \mathrm{mg}$ $\mathrm{kg}^{-1}$ in surface soils of $\mathrm{Hg}$ mining or ore deposits from Great Britain, Canada, Czechoslovakia, U.S., and U.S.S.R. (Kabata-Pendias and Pendias 1995). 
The $\mathrm{Hg}$ contents were varied in the Sunchullí Lake sediments. According to the already mentioned regulatory schemes, sediments could be classified as seriously enriched except for Sediment 4 (Table 1). The $\mathrm{Hg}$ found in the lake sediments come from both places, where the miners use primitive amalgamation processes, and from atmospheric deposition due to distance from the bigger mining operations, as showed the concentration of soil samples taken in the surroundings of the lake (Soils 4, 5, and 6), which ranged between 1.2 and $0.06 \mathrm{mg} \mathrm{kg}^{-1}$.

Based on the analytical data, it is interesting to observe that the $\mathrm{Hg}$ concentrations in water do not seem to be high enough to be detected by the analytical method. Taking into account the detection limit of the method, the values were lower than the levels allowed $\left(0,5 \mu \mathrm{L} \mathrm{L}^{-1}\right)$ by the European Community (DVGW 1985). Contents of $\mathrm{Hg}$ in the sediments (Sediments 3, 4, and 5) varied from 12.3 to $0.1 \mathrm{mg} \mathrm{kg}^{-1}$. If these values are compared with those obtained by Alanoca and Maurice-Bourgoin (2000) for Tuichi River waters ( 0.0145 and $\left.0.047 \mathrm{mg} \mathrm{kg}^{-1}\right)$ in Bolivia, we can suggest that the sediments of the Sunchullí Lake are enriched with great amounts of $\mathrm{Hg}$.

The highest concentration of $\mathrm{Hg}\left(23.7 \mathrm{mg} \mathrm{kg}^{-1}\right)$ was obtained in the Sediment 7 of the Viscachani Lake area, which is similar to the Madeira River (Brazil) sediments concentration (19.83 $\mathrm{mg} \mathrm{kg}^{-1}$ ) (Pfeiffer et al. 1991). This sample was collected close to an area where the primitive amalgamation processes were carried out. $\mathrm{Hg}$ levels in the sediment samples of the lake were very high (23.7 and $11.7 \mathrm{mg} \mathrm{kg}^{-1}$ ) and largely exceeded the thresholds levels established by the already mentioned regulations (NMHPPE 1994; BWRHABTGG 1995; Barth and L'Hermite 1987; BAFUB 1987) and the values reported in the literature (Filho and Maddock 1997; Barbo et al. 2004).

$\mathrm{Hg}$ contents of the lakes and river waters of the Sunchullí-Viscachani area were below the detection limit (Table 1). However, Sediments 3 and 5 from the Sunchullí Lake had high $\mathrm{Hg}$ contents, which we consider to be a potential high risk for the ecosystem. In the Sunchullí River, Sediment
2 was taken close to a point of discharge; the $\mathrm{Hg}$ concentration in this sediment was $102 \mathrm{mg}$ $\mathrm{kg}^{-1}$ which was the highest of all the sediments we analyzed.

$\mathrm{Hg}$ content of the plant (Aciachne sp.) was 1.84 $\mathrm{mg} \mathrm{kg}^{-1}$. According to Kabata-Pendias and Pendias (1992), the background levels of $\mathrm{Hg}$ in vegetables and fruits vary from 2.6 and $86 \mathrm{\mu g} \mathrm{kg}^{-1}$. Therefore the reported value showed a potential accumulation of $\mathrm{Hg}$ in plant tissues for this species in the studied area. Recent works have shown that plant foliage can be a significant sink of atmospheric $\mathrm{Hg}$ (Hanson et al. 1995; Ericksen et al. 2003; Schwesig and Krebs 2003) and that litterfall can be an important source of $\mathrm{Hg}$ to the terrestrial ecosystem (Frescholtz et al. 2003). Plants differ in their ability to take up $\mathrm{Hg}$ and can also develop a tolerance to high $\mathrm{Hg}$ concentration in their tissues when grown in soils overlying $\mathrm{Hg}$ deposits (Kabata-Pendias and Pendias 1992).

\section{The Katantika area}

The $\mathrm{Hg}$ concentration in the Katantica area (Table 2) was lower than in the Sunchullí-Viscachani area. Profile I samples showed values of $\mathrm{Hg}$ lower than the reference concentration given by the used international regulation, therefore no $\mathrm{Hg}$ enrichment was observed in this profile. However, Sediment 1, located next to the mine (Figure 1), presented a Hg concentration of $2.24 \mathrm{mg} \mathrm{kg}^{-1}$ and confirmed that the Katantika Lake exhibited a $\mathrm{Hg}$ enrichment. In the case of the Pelechuco River, $\mathrm{Hg}$ was no detected in the water of the river. Only in the water sample collected from the mining operation drainages towards the Pelechuco River (Water 7) the presence of $\mathrm{Hg}$ was detected (1.93 $\mathrm{gg} \mathrm{L}^{-1}$ ) (Table 2), since the sampling site was close to a mining operations area. Taking into account the levels allowed $(0.5 \mu \mathrm{g}$ $\mathrm{L}^{-1}$ ) by the European Community (DVGW 1985) this water sample was polluted by Hg. Due to the cumulative contribution of the spills along the river, sediments of the lower basin had higher concentrations of $\mathrm{Hg}$ (Table 2). 
Table 2. Properties and $\mathrm{Hg}$ contents of the soil profiles, lake sediments, lake and river waters, and the mine samples in the Katantica area

$\begin{array}{ccccccc}\mathrm{pH} & \begin{array}{c}\text { E. C. } \\ \left.(\mathrm{dS} \mathrm{m})^{-1}\right)\end{array} & \begin{array}{c}\text { O.C. } \\ \left(\mathrm{g} \mathrm{kg}^{-1}\right)\end{array} & \begin{array}{c}\text { C.E.C. } \\ \left(\mathrm{cmol}_{+} \mathrm{kg}^{-1}\right)\end{array} & \begin{array}{c}\text { T. N. } \\ \left(\mathrm{g} \mathrm{kg}^{-1}\right)\end{array} & \begin{array}{c}\text { Clay } \\ \left(\mathrm{g} \mathrm{kg}^{-1}\right)\end{array} & \begin{array}{c}\mathrm{Hg} \\ \left(\mathrm{mg} \mathrm{kg}^{-1}\right)\end{array}\end{array}$

Profile

Haplic Umbrisol

\begin{tabular}{|c|c|c|c|c|c|c|c|}
\hline Profile I - Ah (0-42 cm) & 4.75 & 0.15 & 75.2 & 24.68 & 4.3 & 109.2 & 0.08 \\
\hline Profile I - C (> $42 \mathrm{~cm})$ & 6.40 & 0.04 & 06.6 & 4.14 & 0.5 & 55.0 & 0.02 \\
\hline \multicolumn{8}{|l|}{ Katantica lake } \\
\hline Sediment (1) & 6.48 & 0.32 & 16.7 & 4.56 & 1.7 & 68.2 & 2.24 \\
\hline Sediment (2) & 5.18 & 0.67 & 87.6 & 31.35 & 8.1 & 138.7 & 0.20 \\
\hline Water (1) & 6.87 & 0.035 & -- & -- & -- & -- & BDL \\
\hline Water (2) & 6.79 & 0.047 & -- & -- & -- & -- & BDL \\
\hline \multicolumn{8}{|l|}{ Pelechuco River } \\
\hline $\begin{array}{l}\text { Sediment (3) upstream } \\
\text { discharge }\end{array}$ & 6.35 & 0.07 & 08.4 & 1.99 & 1.0 & 19.0 & 0.08 \\
\hline $\begin{array}{l}\text { Sediment (4) upstream } \\
\text { discharge }\end{array}$ & 7.27 & 0.29 & 6.2 & 1.11 & 0.3 & 12.5 & 0.04 \\
\hline $\begin{array}{l}\text { Sediment (5) downstream } \\
\text { discharge }\end{array}$ & 7.03 & 0.55 & 6.3 & 0.96 & 0.3 & 10.0 & 8.55 \\
\hline $\begin{array}{l}\text { Sediment (6) downstream } \\
\text { discharge }\end{array}$ & 7.41 & 0.27 & 33.1 & 4.84 & 3.6 & 418.7 & 6.85 \\
\hline Water (3) upstream discharge & 6.51 & 0.068 & -- & -- & -- & -- & BDL \\
\hline Water (4) upstream discharge & 6.97 & 0.051 & -- & -- & -- & -- & BDL \\
\hline $\begin{array}{l}\text { Water (5) downstream } \\
\text { discharge }\end{array}$ & 7.13 & 0.037 & -- & -- & -- & -- & BDL \\
\hline $\begin{array}{l}\text { Water (6) downstream } \\
\text { discharge }\end{array}$ & 7.18 & 0.072 & -- & -- & -- & -- & BDL \\
\hline $\begin{array}{l}\text { Water from mining area towards } \\
\text { river }(7)\end{array}$ & 6.93 & 0.069 & -- & -- & -- & -- & $1.93^{*}$ \\
\hline \multicolumn{8}{|l|}{ Mine area } \\
\hline Sediment (7) & 6.40 & 0.30 & 4.7 & 0.31 & 0.3 & 7.0 & 31.80 \\
\hline Residual (1) & 4.90 & 0.30 & 6.3 & 0.81 & 0.3 & 0.0 & 17.23 \\
\hline Water (8) & 5.70 & 0.086 & -- & -- & -- & -- & $0.73^{*}$ \\
\hline
\end{tabular}

BDL: below the detection limit $\left(0.5 \mu \mathrm{g} \mathrm{L}{ }^{-1}\right)$; NM: not measured due to saturation of equipment; E.C.: electrical conductivity; O.C.: organic carbon; T.N.: total nitrogen; C.E.C.: cation exchange capacity. ${ }^{*}$ Concentration in $\mu \mathrm{L} \mathrm{L}^{-1}$.

The $\mathrm{Hg}$ concentration in the residual from the mining operation was $17.23 \mathrm{mg} \mathrm{kg}^{-1}$. The $\mathrm{Hg}$ level in water associated with the mining site (Water 8) was $0.73 \mu \mathrm{g} \mathrm{L}^{-1}$. If this value is compared to the one obtained in the Tapajos River, Brazil, which was less than 1.7 and $1.9 \mathrm{ng} \mathrm{L}^{-1}$ for the wet and dry seasons, respectively (Roulet et al. 1998), the aquatic ecosystems of Pelechuco River can be affected for a potential source of $\mathrm{Hg}$ pollution. In addition, according with the European regulation (DVGW 1985), this water sample is polluted by $\mathrm{Hg}$. 
The Sural area

When comparing the data of the soil profiles from the Sunchullí-Viscachani area with the Hg concentration in the soil profiles from the Sural area, atmospheric deposition of $\mathrm{Hg}$ does not occur in the areas close to Profiles I and II (Table 3). This is likely due to the fact that the extraction of gold in this area is less developed than in the other studied areas, and thus the deposition of $\mathrm{Hg}$ occurs near the emission source. Therefore, we can suggest that only the nearby terrestrial ecosystems and the workers could be at risk, since the amalgamation is a local process.

The $\mathrm{Hg}$ concentrations of the surface soils from the Sural Lake were similar to the surface soils of the Sunchullí Lake area. Hg concentrations in sediments and surface soils did not reach high values ( $<0.6 \mathrm{mg} \mathrm{kg}^{-1}$, Table 3 ). $\mathrm{Hg}$ contents in the water of the lake were also similar to the values found in the Sunchullí Lake, which was < $0.5 \mu \mathrm{L} \mathrm{L}^{-1}$.

Content of $\mathrm{Hg}$ in the plant tissues was $0.16 \mathrm{mg}$ $\mathrm{kg}^{-1}$ which was lower than the value reported for the plant sample in the Sunchullí-Viscachani area. This is likely due to the plant growth on soils with low concentrations of $\mathrm{Hg}$ and a low impact of atmospheric deposition. In general, $\mathrm{Hg}$ content of plants is high when $\mathrm{Hg}$ content of soil is also high, but this relation does not always stands (Siegel et al. 1987).

$\mathrm{Hg}$ water concentration in the Sural River was below the detection limit. Therefore, this water does not currently pose any risk for aquatic ecosystems and human health (Table 3).

Table 3. Properties and $\mathrm{Hg}$ content of the two surface soil, sediment, water, and plant samples in the Sural area

\begin{tabular}{|c|c|c|c|c|c|c|}
\hline $\mathrm{pH}$ & $\begin{array}{c}\text { E. C. } \\
\left(\mathrm{dS} \mathrm{m}^{-1}\right)\end{array}$ & $\begin{array}{l}\text { O.C. } \\
\left(\mathrm{g} \mathrm{kg}^{-1}\right)\end{array}$ & $\begin{array}{c}\text { C.E.C. } \\
\left(\mathrm{cmol}_{+} \mathrm{kg}^{-1}\right)\end{array}$ & $\begin{array}{l}\text { T. N. } \\
\left(\mathrm{g} \mathrm{kg}^{-1}\right)\end{array}$ & $\begin{array}{l}\text { Clay } \\
\left(\mathrm{g} \mathrm{kg}^{-1}\right)\end{array}$ & $\begin{array}{c}\mathrm{Hg} \\
\left(\mathrm{mg} \mathrm{kg}^{-1}\right)\end{array}$ \\
\hline
\end{tabular}

Profile

\begin{tabular}{|c|c|c|c|c|c|c|c|}
\hline \multicolumn{8}{|l|}{ Lithic Leptosol } \\
\hline Profile I - Ah $(0-9 \mathrm{~cm})$ & 5.09 & 0.37 & 43.7 & 15.21 & 4.6 & 95.7 & 0.06 \\
\hline Profile I - R (>9 cm) & -- & -- & -- & -- & -- & -- & -- \\
\hline \multicolumn{8}{|l|}{ Fibric Histosol } \\
\hline Profile II - H (0-27 cm) & 4.04 & 0.11 & 59.8 & 61.01 & 17.0 & 150.8 & 0.07 \\
\hline Profile II - R (>27 cm) & -- & -- & -- & -- & -- & -- & -- \\
\hline \multicolumn{8}{|l|}{ Sural lake } \\
\hline Soil (1) & 7.32 & 0.43 & 8.4 & 4.96 & 1.2 & 71.6 & 0.62 \\
\hline Soil (2) & 7.38 & 0.13 & 7.9 & 3.97 & 1.5 & 204.9 & 0.02 \\
\hline Sediment (1) & 6.94 & 0.17 & 11.8 & 5.56 & 1.0 & 127.1 & 0.07 \\
\hline Sediment (2) & 6.18 & 0.14 & 62.9 & 11.42 & 4.4 & 504.9 & 0.23 \\
\hline Water (1) & 6.81 & 0.034 & -- & -- & -- & -- & BDL \\
\hline Water (2) & 6.83 & 0.055 & -- & -- & -- & -- & BDL \\
\hline \multicolumn{8}{|l|}{ Sural River } \\
\hline Water (3) & 6.85 & 0.061 & -- & -- & -- & -- & BDL \\
\hline Plant & -- & -- & -- & -- & -- & -- & 0.16 \\
\hline
\end{tabular}

BDL: below the detection limit $\left(0.5 \mu \mathrm{g} \mathrm{L}{ }^{-1}\right)$; NM: not measured due to saturation of equipment; E.C.: electrical conductivity; O.C.: organic carbon; T.N.: total nitrogen; C.E.C.: cation exchange capacity. 


\section{Conclusions}

Analytical data have confirmed a high level of $\mathrm{Hg}$ pollution in two of the three areas studied. Among the three sites, the Sunchullí-Viscachani area must have received a very high amount of atmospheric deposition of $\mathrm{Hg}$ as well. This may be due to the open topographic position in comparison to the other two areas. Therefore, the risk for the ecosystems and inhabitants of the region is very high.

$\mathrm{Hg}$ contents of the majority of water samples from lakes and rivers of the three areas were below the detection limit. However, $\mathrm{Hg}$ concentrations found in some sediments were high, indicating that an enrichment of $\mathrm{Hg}$ in the sediments has occurred. The highest concentration of $\mathrm{Hg}$ was found in the river sediment of the SunchulliViscachani area. This points out the degree of contamination in the mining area. In our view, this area is likely one of the heavily Hg-contaminated sites in the world. Accumulation of $\mathrm{Hg}$ was also found in plants tissues. Therefore, there is an urgent need to study $\mathrm{Hg}$ transformation of inorganic $\mathrm{Hg}$ to organic $\mathrm{Hg}$ species (MeHg), i.e bioaccessibility and speciation in soils and sediments in the Apolobamba area.

\section{Acknowledgements}

This study was carried out with the assistance of the Spanish Agency for International Cooperation within the framework of the AraucariaApolobamba Program. 


\section{REFERENCES}

- Alanoca L, Maurice-Bourgoin L. 2000. Estudio de la contaminación por mercurio en la cuenca alta del Río Tuchi. La Paz, Bolivia.

- Anne P. 1945. Sur le dosage rapide du carbone organique des sols. Annales de Agronomie 2:162-172.

- BAFUB 1987. Available from: www.gama-peru.org/ libromedmin/.

- Barbo ES, Angélica RS, Silva AP, Faial KRF, Mascarenhas AFS, Santos ECO, Jesus IM, Loureiro ECB. 2004. Assessment of Mercury Levels in Soils, Waters, Bottom Sediments and Fishes of Acre State in Brazilian Amazon. Water, Air, Soil Poll. 147:61-77.

- Barth H, L'Hermite P, editors. 1987. Scientific Basis for Soil Protection in the European Community. Comission of the European Communities. London: Elsevier Applied Science.

- Bergan T, Gallardo L, Rodhe H. 1999. Mercury in the global troposphere: a three-dimensional model study, Atmospheric Environment 33:1575-1585.

- Bower CA, Wilco Wilcox LV. 1965. Soluble salts. In: Black CA, editor. Methods on Soil Analysis. Madison, Wisconsin, U.S.A.: American Society of Agronomy. p. 933-940.

- BWRHABTGG, 1995. Besluit van de Vlaamse Regering Houdende Achtergrondwaarden. Bodernsaneringsnomen en Toepassingen van Gereinigde Grond. Brussels, Belgium: Ministry of Environment and Employment.

- Campo L. 2003. Programa Araucaria. Componentes Programa Araucaria, Resultados Cartográficos. p. 29-47.

- Chapman HD. 1965. Cation exchange capacity. In: Black CA, editor. Methods of Soil Analysis. Madison, Wisconsin, U.S.A.: American Society of Agronomy. p. 891-900.

- Duchaufour P. 1970. Precis de Pedologie. Paris: Masson. $481 \mathrm{pp}$.

- DVGW. 1985. Available from: www.gama-peru.org/ libromedmin/.

- Enríquez JC. 2001. Minería, Minerales y Desarrollo Sustentable en Bolivia. La Paz. Bolivia: Servicios Ambientales.

- Ericksen JA, Gustin MS, Schorran DE, Johnson DW, Lindberg SE, Coleman JS. 2003. Accumulation of atmospheric mercury in forest foliage. Atmos. Environ. 37:1613-1622.
- FAO-ISRIC. 2006. Guidelines for Soil Description (revised), fourth ed. Rome: F.A.O. 97 pp.

- Filho SR, Maddock JEL. 1997. Mercury pollution in two gold mining areas of the Brazilian Amazon. J. Geochem. Explor. 58:231-240.

- Frescholtz TF, Gustin MS, Schorran DE, Fernandez GCJ. 2003. Assessing the source of mercury in the foliar tissue of Quaking Aspen. Environ. Toxicol. Chem. 22:2114-2119.

- Hanson PJ, Lindberg SE, Tabberer TA, Owens JG, Kim KH. 1995. Foliar exchange of mercury vapor: evidence for a compensation point. Water Air Soil Pollut. 80:373-382.

- Horvat M, Nolde N, Fajon V, Jereb V, Logar M, Lojen S, Jacimovic R, Falnoga I, Faganeli J, Drobne D. 2003. Total mercury, methylmercury and selenium in mercury polluted areas in the province Guizhou, China. Sci. Total Environ. 304:231-256.

- Hylander LD, Silva EC, Oliveira LJ, Silva SA, Kuntze EK, Silva DX. 1994. Mercury levels in Alto Pantanal: A screening study. Ambio 23:478-484.

- Kabata-Pendias A, Pendias H. 1995. Trace Elements in Soils and Plant. Boca Raton, USA: CEC Press. 365 pp.

- Lamborg CH, Fitzgerald WF, Damman AWH, Benoit JM, Balcom PH, Engstrom DR. 2002. Modern and historic atmospheric mercury fluxes in both hemispheres: Global and regional mercury cycling implications. Globlal Biogeochem. Cycles 16(4): 1104.

- Lechler PJ, Miller JR, Lacerda LD, Vinson D, Bonzongo JC, Lyons WB, Warwick JJ. 2000. Elevated mercury concentrations in soils, sediments, water, and fish of the Madeira River basin, Brazilian Amazon: a function of natural enrichments?. Sci. Total Environ. 260:87-96.

- Lindberg SE, Owens JG, Stratton WJ. 1994. Application of throughfall methods to estimate dry deposition of mercury. In: Watras CJ, Huckabee JW, editors. Mercury Pollution: Integration and Synthesis. Chelsea, MI: Lewis Publishers. p. 261-271.

- Lindquist O, Rhode H. 1985. Atmospheric Mercury-a review. Tellus 37B:136-159.

- Mason RP, Sheu G. 2002. Role of ocean in global mercury cycle. Global Biogeochemical Cycles 16:1-14.

- Maurice-Bourgoin L, Aalto R, Fraizy P, Barnaud V, Guyot JL. 2001. Modulation of Mercury Transport trough Fluvial System by Channel-Floodplain Interaction: A case study for the Beni River, Bolivian Amazonia. In: 6th Int. Conference on Mercury as a global pollutant; 2001 Oct 15-19; Akagi, Minamata, Japan. 
- Ministerio de Minería Metalurgia de Bolivia. 1993. Desarrollo de la Minería y la Metalurgia en Bolivia: Fondo y Perfil Preliminar del Proyecto, "Regulaciones Ambientales para la Industria Minera. Swedish Geological, SGAB International AB.

- Muñoz MA, Faz A. 2009. Soil-plant conservation in the vicuna (Vicugna vicugna) habitat in Apolobamba, Bolivia: biodiversity in high altitude grasslands. In: Faz Cano A, Arocena JM, Mermut AR, Ortiz Silla R. editors. Land Degradation and Rehabilitation-Dryland Ecosystems. Reiskirchen: Catena Verlag. Advances in Geology 40:97-108.

- NMHPPE. 1994. Netherlands Ministry of Housing. Physical Planning and Environment. Leidschendam, Holland.

- Pacyna EG, Pacyna JM, Steenhuisen F, Wilson SJM. 2006. Global anthropogenic mercury emission inventory for 2000. Atmospheric Environment 40:4048-4063.

- Pacyna J, Pacyna E. 2002. Global emissions of mercury from anthropogenic sources in 1995. Water, Air and Soil Pollution 137:149-165.

- Peech M. 1965. Hidrogen-ion activity. In: Black CA, editor. Methods or Soil Analisis. Madison, Wisconsin, U.S.A.: American Society of Agronomy. p. 914-916.

- Peñaloza M, Reinhardty I. 2000. Problemas ambientales de la minería Boliviana. Estudio de caso de la minería en el área de la ciudad de Potosí, Proyecto IDRC - WRI - CIPMA: Identificando los Impactos Económicos y Ambientales de la Liberalización del Comercio: Una Aplicación al Sector Minero. Fundación MEDMIN.

- Pfeiffer WC, Maim O, Souza CMM, Drude de Lacerda L, Silveira EG, Bastos WR. 1991. Mercury in the Madeira River ecosystem, Rondonia, Brazil. For. Ecol. Manage. 38:239-245.

- Pirrone N, Keeler GJ, Nriagu JO. 1996. Regional differences in worldwide emissions of mercury to the atmosphere. Atmos. Environ. 30:2981-2987.

- Ramírez V, Terán N. 2.002. Informe de trabajo de campo: Inventariación de actividades Mineras e impactos ecológicos y socioeconómicos en el Área Natural de Manejo Integrado Apolobamba. La Paz, Bolivia: Conservación Internacional/CEPF.

- Roulet M, Lucotte M, Canuel R, Rheault I, Tran S, De Freitos Gog YG, Farella N, Souza do Vale R, Sousa Passos CJ, De Jesus da Silva E, Mergler D, Amorim M. 1998. Distribution and partition of total mercury in waters of the Tapajos River Basin, Brazilian Amazon. Sci. Total Environ. 213:203-211.
- Schwesig D, Krebs O. 2003. The role of ground vegetation in the uptake of mercury and methylmercury in a forest ecosystem. Plant. Soil. 253:445-455.

- Seibert, P. 1993. Ecología en Bolivia. Instituto de Ecología-Universidad Mayor de San Andrés. Revista de Ecología № 20. La Paz. 84 pp.

- Seigneur C, Vijayaraghavan K, Lohman K, Karamchandani P, Scott C. 2004. Global attribution for mercury deposition in the United States. Environmental Science \& Technology 38:555-569.

- Shia RL, Seigneur C, Pai P, Ko M, Sze ND. 1999. Global simulation of atmospheric mercury concentrations and deposition fluxes. Journal of Geophysical Research 104:23747-23760.

- Siegel SM, Siegel BZ, Barcgigiani C, Aratani K, Penny P, Penny D. 1987. A contribution to the environmental biology of mercury accumulation in plant. Water Soil Pollution 33:65-75.

- Travnikov O. 2005. Contribution of the intercontinental atmospheric transport to mercury pollution in the Northern Hemisphere. Atmos. Environ. 39:7541-7548.

- USEPA. 2000. Mercury transport and fate in watersheds. US EPA Office of Research and Developmen's Science to Achive Results (STAR). A product of the National Center for Environmental Research Vol. 4(1):1-8.

- WRB. 2006. World Reference Base for Soil Resource. Rome: F.A.O. 90 pp.

- Zang-Ho S, Ki-Hyun K, Min-Young K, Meehye L. 2005. Modelling study of reactive gaseous mercury in the urban air. Atmos. Environ. 39:749-761. 